\title{
UTILIZATION OF STREAMING TECHNOLOGY AS A PUSDAI TV DAKWAH COMMUNICATION MEDIA
}

\author{
Oleh: \\ Yulia Sariwaty S \\ Diny Fitriawati ${ }^{1}$ \\ Inke Nuari
}

\begin{abstract}
Advances in information technology provide easy access for religiousinstitutions to communicate and socialize with the wider community. Including facilitating the way for the syiar Islam or better known as Dakwah. One of the contemporary da'wah media that utilizes streaming technology is Pusdai TV. This study aims to analyze the use of streaming technology as a medium and communication strategy for da'wah communication by Pusdai TV. This study uses a qualitative research method with a phenomenological approach. Data collection techniques were carried out by means of observation, interviews, and document analysis. The results showed that the first Pusdai TV da'wah communication strategy included message planning through objectives, media selection, main ideas, and audience analysis. Second, the strategic process of making broadcast programming through the stages of idea research, content creation, evaluation and control. Third, the da'wah communication strategy is carried out through internal and external approaches. With all the strategies that have been implemented, active audience feedback is obtained, spiritual fulfillment of audience needs, and audience loyalty.
\end{abstract}

Keywords: Streaming, Media, Communication, Dakwah.

\begin{abstract}
ABSTRAK
Kemajuan teknologi informasi memberikan akses kemudahan bagi lembaga keagamaan dalam melakukan komunikasi dan sosialisasi dengan masyarakat secara luas. Termasuk memudahka $\mathrm{n}$ jalan untuk syiar Islam atau yang lebih dikenal dengan istilah dakwah. Salah satu media dakwah kontemporer yang memanfaatkan teknologi streaming adalah Pusdai TV. Penelitian ini bertujuan untuk menganalisis pemanfaatan teknologi streaming sebagai media dan strategi komuni kasi dakwah oleh Pusdai TV. Penelitian ini menggunakan metode penelitian kualitatif dengan pendekatan fenomenologi. Teknik pengumpulan data dilakukan dengan cara observasi, wawancara, serta analisis dokumen. Hasil yang diperoleh menunjukan, strategi komuni kasi dakwah Pusdai TV yang pertama meliputi perencanaan pesan dilakukan melalui tujuan, pemiliha $\mathrm{n}$ media, ide pokok, serta analisis audience. Kedua, proses strategi pembuatan program tayangan melalui tahapan riset ide, pembuatan konten, serta evaluasi dan kontrol. Ketiga, strategi komunikasi dakwah yang dilakukan melalui pendekatan internal dan ekster nal. Dengan semua strategi yang telah dilakukan, maka didapatkan feedback audience aktif, pemusan kebutuha $\mathrm{n}$ audience secara spiritual, dan loyalitas audience.
\end{abstract}

Kata Kunci: Streaming, Media, Komunikas i, Dakwah.

${ }^{1}$ Program Studi Ilmu Komunikasi Universitas ARS, Jln. Terusan Sekolah No. 1-2, Cicaheum, Kec.

Kiara Condong, Bandung, Jawa Barat. Email; Diny.Fitriawaty @ gmail. com

Program Studi Ilmu Komunikasi - Institut Bisnis dan Informatika Kwik Kian Gie 


\section{INTRODUCTION}

In the modern era like now, the human need for spiritual supplements is quite high, as an effort to balance life activities physically and spiritually. Religious activities are a good thing in the midst of people's busyness in this mobile era. Easy access to related information should provide facilities in the form of media or alternative means that can convey various religious information, such as one of the studies of Islam

Seeing the community's need for religious activities, the West Java Islamic Da'wah Center or better known as the West Java Pusdai built a media, namely Pusdai TV. Pusdai TV is an internet television media that was born from the vision of building a civilization of the people through creative, innovative and Islamic TV programs that can be accessed through the pusdaitv.com streaming channel. The role of the media is very important for the process of delivering da'wah.

By using mass communication, Islamic dissemination and broadcasting activities will be easily accepted by the public. The use of new media or the internet today has transformed into one of the trusted portals in establishing communication, exchanging ideas, and a place for the flow of information.

New media emerged as a result of the development of the mass media. One of the mass media that is updating its technol ogy system is television, which is now starting to develop into streaming television. Streaming TV is a television program service that is broadcast via a web page and can only be accessed if the audience has an internet connection whose content is always updated, is not static, follows the development of events that occur in the surrounding environment, and can be accessed by the public freely with various various forms of distribution.
Streaming TV as a new media makes it easier for the audience to choose message reception, respond to messages, exchange information and always connect with other audiences directly in another sense, which facilitates mutual access to communicati o $\mathrm{n}$. Another advantage of streaming TV lies in the ease of access as long as it is supported by the strong availability of internet technol ogy signals and the reach of a wide audience.

As an institution that carries out da'wah missions, Pusdai TV utilizes streaming technology to facilitate dakwah communication with the Muslim communi ty at large.

\section{LITERATURE REVIEW Mass Communication}

In Berger and Chaffee's opinion, mass communication is a science that tries to understand the production, processing, and effects of symbol and signal systems by building testable theories, containing valid generalizations that explain phenomena related to production, processing, and effects (McQuail, 2011: 17).

Basically mass communication is communication through mass media (print and electronic media). Because, at the beginning of its development, mass communication came from the development of the word media of mass communication (Nurudin, 2009: 3-4).

In mass communication there is a media update or better known as new media. Deden W. Prayugo explained that: "New media can be understood not only as new media appearing in communication media. Media emerge from old media innovations that are less relevant.

In new media there is a technological development, namely streaming technology. Streaming technology is a technology used to play audio and video files broadcast directly 
or indirectly (pre record) and is under a netw ork of servers. The audio and video files that will be broadcast are placed on a computer server that can be directly accessed via a client computer via an internet connection. "The gap supports sending files in the form of audio and video in real time" (Wibow o \& Amin, 2018: 307).

\section{Dakwah}

The word da'w ah comes from Arabic which is a form of mashdar from the word da'a, yad'u, which means an appeal, invitation, or call. By definition, M. Isa Anshary explains that, "preaching Islamiyah means conveying the call of Islam, inviting and calling mankind to accept and believe in Islamic beliefs and views of life". (Zulkarnaini, 2015: 155).

Da'wah communication is a new study in the world of communication science. In addition, Da'wah Communication is also a field of study that is specifically related to the Muslim community or community (Muslims) considering that the terminology of da'wah itself belongs only to Islam Da'wah communication can also be defined as communication that involves da'wah messages and da'wah actors or commonly referred to as Da'i which is related to Islamic teachings and their practice in various aspects of life.

\section{RESEARCH METHODS}

The researcher chose to use qualitative research methods to determine the procedure for finding, collecting, processing and analyzing research data. Qualitative research has different meanings for each moment, however, the general definition of qualitative research is a multiple method in focus, involving an interpretive and reasonable approach to each subject matter. This means that qualitative research works in a natural setting, which seeks to understand, interpret phenomena as seen from the meaning that people give them

Djamian Satori \& Aan Komariah argues that "qualitative research is a process of inquiry about understanding based on separate methodological traditions; clear checks that explore a social or human problem ". (Nurfitriani \& Suhartini, 2018: 68).

Phenomenology is a research approach used by researchers in an effort to reveal the similarity of meaning which is the essence of a concept or phenomenon that is consciously and individually experienced by a group of individuals in their life.

In this study, phenomenology $w$ as chosen because the experiences felt by the congregation as Pusdai TV audiences in consuming da'wah shows through streaming netw orks can be said to be the same. The thing that makes it the same is of course not from the media itself, but rather the people's need for easy and effective preaching, of course accompanied by the times and advances in information technology that play a central role.

\section{RESULTS AND DISCUSSION Strategy and Planning of Pusdai TV's Da'wah Program Message}

In a communication strategy, to achieve effective communication, a good message planning is required so that the results achieved are in accordance with what is desired. In message planning, objectives are the main basis for determining how the communication message planning process will be carried out. Pusdai TV utilizes streaming technology as a medium for da'wah, and the broadcast program of da'wah has the aim of spreading the mission of da'wah Islamiyah to the public. It is in line with Pusdai TV's slogan, namely "Windows 
of Indonesian Islam".

Pusdai TV as a medium has cognitive and conative goals. Cognitively, the program broadcast by Pusdai TV is certainly informative and adds to knowledge and insight in religious terms. Meanwhile, the conative objective is as a medium that carries out the mission of da'wah which is based on the Al-Quran and hadith as a source of guidance for all Muslims.

Pusdai TV chooses to use new media with the support of the internet in broadcasting live streaming of its broadcast programs, due to its wide coverage area, so that the audience's reach is not only limited to the city of Bandung, but can reach other cities in Indonesia and even around the world.

The development of technology is an inspiration for Pusdai TV to spread da'wah widely with streaming technology. The internet is included in technological developments, the internet is the main component that supports the broadcasting of Pusdai TV programs.

Pusdai TV analyzes the audience based on the audience's character and analyzes their demographics so that information about the audience's needs is formed and what kind of messages to convey. Several types of messages aim to motivate the audience to change their behavior. So an approach is needed by providing rational and convention arguments.

\section{Production Strategy of Pusdai TV's Da'wah Program}

In order to achieve the effectiveness of a communication strategy process, apart from depending on the content of the message that attracts attention, it must be adapted to the conditions and needs of the audience, because it also affects the delivery method used. The way to convince the audience in the communication strategy process is carried out by steps that include showing the programs that the audience needs, the process of making the shows that the audience needs, and what information is distributed by Pusdai TV.

Pusdai TV implements da'wah strategies to attract audiences as a strategy for broadcasting programs. There are many audiences who need da'wah content in their daily lives, for that Pusdai TV tries to accommodate these needs to be made into content or program programs.

In making shows, Pusdai TV conducts research to determine what shows will be made. There are three types of process for making a program at Pusdai TV. The first is the program created specifically by Pusdai $\mathrm{TV}$, the second is the program created specifically by Pusdai and the government, and the third is a program created based on an initiative, where the program or broadcast is not included in the agenda to be broadcast but has benefits for the audience, then Pusdai TV took the initiative to broadcast the program

The information disseminated by Pusdai TV is not only about da'wah studies, but also contains other information that the audience needs. Some of the information that will be distributed by Pusdai TV will be reviewed before broadcasting, this is done in order to minimize errors due to human errors.

In the production of Pusdai TV programs, the role of the creative team is negated because all programs or content are made by the producer. This is because Pusdai TV does not have adequate team members. However, in creating content Pusdai TV will be assisted by students who carry out an internship program which is always available every period.

Pusdai TV always does research before creating a program or content. Usually, Pusdai TV will observe via the internet regarding things that are currently being discussed by the audience, and Pusdai TV will find out what themes the audience is 
looking for. The use of the internet for research is deemed effective by Pusdai TV.

\section{Pusdai TV's Communication Approach in Improving the Existence of Da'wah Programming}

The communication approach is one way for communication effectiveness where the message conveyed will be right on target. Pusdai TV carries out two types of approaches, namely an internal approach and an external approach. The internal approach was taken from Pusdai TV crew members to other members. This is done so that each member has the same voting rights in conveying an idea. This is also done to maintain the organizational climate.

Apart from the internal approach, there is also an external approach taken by Pusdai TV to the community as the audience. This is done to increase the popularity of Pusdai TV as a media that can be chosen by the public.

The external approach taken by Pusdai TV is a resonant approach. The resonance approach is also known as an approach that focuses on the state or condition of consumers in their lives. This communication approach emphasizes the lifestyle of the audience. Where at the present time, the community as the audience prefers practical things including spiritual needs such as preaching.

Furthermore, in the rational approach, it is said in the rational approach that this communication approach focuses on practical consumer needs, where the information conveyed in this approach is in the form of facts that are packaged in the form of persuasion. In this case, Pusdai TV as a streaming media in increasing the existence of da'wah which is displayed in this rational approach is a fact which is useful to attract consumers to enjoy it.

Lastly is the Brand image approach.
In line with Shimp's opinion, the brand image approach involves more psychological differentiation than just physical differentiation.

The purpose of the internal and external approaches carried out by Pusdai is none other than to achieve effective communication. The effective communication that Pusdai TV wants to achieve through an internal approach is the creation of an exchange of information and ideas between Pusdai TV members. Meanwhile, the purpose of the external approach taken by Pusdai TV to the public as an audience is to achieve effective communication in delivering mass messages and the message can be easily accepted by the audience.

\section{Community Feedback on the Pusdai TV}

Pusdai TV as a communicator must have the ability to interpret the cues or symptoms shown by the audience who then take the necessary actions to improve the situation. The quality of broadcast is very important to support the success of a media in conveying messages. This also applies when Pusdai TV creates a program to broadcast so that what is said can be well received by the audience.

In the observations that the researchers conducted, there were differences in findings with the results of interviews with resource persons. According to the informants, the quality of broadcasts from Pusdai TV was well received by the public, but the researchers found that the quality of Pusdai TV's shows was still not good in terms of video quality. This can be seen in several videos uploaded to the Pusdaitv youtube channel.

The researcher further analyzes that the high video compression done by Pusdai TV causes a decrease in the quality of the video that is produced. Even so, the audience 
of Pusdai TV was still satisfied and felt that the broadcast $w$ as good enough for them. Even so, the audience of Pusdai TV was still satisfied and felt that the broadcast was good enough for them

Pusdai TV tries to be an effective media for the audience, because as explained at the beginning, Pusdai TV aims to spread Islamic preaching to the community thr ough the media. This means that pusdai TV is not oriented towards profit, but more towards religious broadcasts.

\section{CONCLUSIONS AND SUGGESTIONS}

Conclusions from the research results, namely: The message planning carried out by Pusdai TV as a means of communication for da'wah is to formulate a strategy from the start, namely by setting goals as a medium of communication and socialization of Islamic da'wah. After that, determine the media that will be used, namely by utilizing streaming technology. Furthermore, determining the main idea of technological developments in the spread of da'wah, and the last is evaluation of audience feedback to determine the needs of the audience.

The communication strategy carried out by Pusdai TV as a means of communication for da'wah is to create attractive programs when presented to the audience. Determine what information will be conveyed, then carry out the implementation of the plans that have been prepared, including developing the overall informati on that has been presented.

The communication approach taken by Pusdai TV is to approach internally and externally. The internal approach is carried out by a member or crew of Pusdai TV. While the external approach is carried out by Pusdai TV to the community. The external approach is carried out with three types of approaches, namely the Brand image, resonance, and rational approach. The approaches taken by Pusdai TV aim to build communication effectiveness.

Public feedback on Pusdai received a positive response, on average the informants expressed their satisfaction with the broadcast programs broadcast by Pusdai TV via streaming. This is also strengthened by the audience's need for da'wah content, because, on average, the audience from Pusdai TV are congregants from the Pusdai mosque who make Pusdai TV shows as an alternative if they cannot follow the study directly at the mosque.

Researcher's suggestion for Pusdai TV is related to direct observation findings of broadcasts. It is better if the production department makes improvements to the video quality for the television program, so that the image quality received by the audience is good and clear. So that there is no difference in perception

\section{REFERENCES}

Effendy, Onong Uchjana. 2009. Ilmu Komunikasi Teori dan Praktik. Bandung: Remaja Rosdakarya.

McQuail. 2011. Teori Komunikasi Massa. Jakarta: Salemba humanika.

Nurudin. 2011. Pengantar Komunikasi Massa. Depok: Rajawali Pers.

Nurfitriani, A., \& Suhartini, T. (2018). Strategi Marketing Public Relations Pt. Pos Indonesia. Jurnal Ilmu Komunikasi (J-IKA), V(1), 66-70. Retrieved from https://ejournal.bsi.ac.id/ejurnal/index. php/jika/article/view/3657

Prayugo, D. W. (2018). Pengaruh Komuni tas Virtual Terhadap Minat Beli Online Pada Grup Facebook Bubuhan Samarinda, 6(1), 143-157.

Purnomo, E. (2017). Strategi Komunikasi Badan Pemberdayaan Perempuan, Perlindungan Anak Dan Keluarga 
Berencana Dalam Mewujudkan Program Kabupaten Layak Anak Di Kabupaten Siak. JOM FISIP Vol., 4(1), $1-15$.

Suprapto, Tommy. 2009. Pengantar Teori \& Manajemen Komunikasi. Yogyakarta: MedPress

Tumpi. 2017. 14 Tipe Shot Dalam Pengambilan Gambar Film, (Online), (https://tumpi.id/14-tipe-shot-dalampengambilan-gambar-fil m/. Diakses 18 Februari 2020).

Udasmoro, W. (Ed.). (2017). Dari Doing Ke Undoing Gender (Teori Dan Praktik Dalam Kajian Feminisme). Gadjah Mada University Press.

van Leeuwen, Theo. 2005. Introducing Social Semiotics. London \& New York: Routledge.

van Leeuwen, Theo. 2015. Multimodali ty. Dalam Deborah Tannen, Heidi E. Hamilton dan Deborah Schiffrin (eds), The Handbook of Discourse Analysis. Edisi 2. John Wiley \& Sons, Inc. hlm 447-462.

Video Advertisements: The Case of bell). Dalam Discurso \& Sociedad,1394), $\mathrm{hlm}$ 765-797. http://w ww.dissoc.org/ediciones/v13n0 4/DS13(4)Screti.

VIVA. 2018. Blued, Aplikasi Pecinta Sesama Jenis dengan 27 Juta Pengguna, (Online), (https://w ww.viva.co.id/arsip/996784blued-aplikasi-pecinta-sesama-jenisdengan-27-juta-pengguna. Diakses 9 November 2019).

Wibowo, A. T., \& Amin, F. M. (2018). TEKNOLOGI LIVE STREAMING Media Penunjang Dakwah dan Kegiatan Belajar Mengajar Untuk Mendukung Cyber University. PROCEEDINGS: Annual Conference for Muslim Scholars, 1, 306-313.
Woodw ard, Kathryn (ed.). 2002. Identity and Difference. London: SAGE Publications.

Yulius, Hendri. 2019. C*BUL: Perbincangan Serius tentang Seksualitas Kontemporer. Tangerang Selatan: Marjin Kiri.

Zulkarnaini, Z (2015). Dakwah Islam di Era Modern. Risalah, 26(3), 151-158. Retrieved from http://ejournal.ui nsuska.ac.id/index.php/risalah/article/vi ew/1271\%5Cnhttp://ejournal.uinsuska.ac.id/index.php/risalah/article/do wnload/1271/1139 